\title{
Article \\ Educational Resources for Geoethical Aspects of Water Management
}

\author{
Sebastian Handl ${ }^{1}\left(\mathbb{D}\right.$, Cristina S. C. Calheiros ${ }^{2}\left(\mathbb{D}\right.$, Markus Fiebig $^{3}$ and Guenter Langergraber ${ }^{1, *}$ \\ 1 Department of Water, Atmosphere and Environment, Institute of Sanitary Engineering and Water Pollution \\ Control, University of Natural Resources and Life Sciences, Vienna (BOKU), Muthgasse 18, \\ 1190 Vienna, Austria; sebastian.handl@boku.ac.at \\ 2 Interdisciplinary Centre of Marine and Environmental Research (CIIMAR/CIMAR), University of Porto, \\ Novo Edifício do Terminal de Cruzeiros do Porto de Leixões, Avenida General Norton de Matos, S/N, \\ 4450-208 Matosinhos, Portugal; cristina@calheiros.org \\ 3 Department of Civil Engineering and Natural Hazards, Institute of Applied Geology, \\ University of Natural Resources and Life Sciences, Vienna (BOKU), Peter-Jordan-Straße 82, \\ 1190 Vienna, Austria; markus.fiebig@boku.ac.at \\ * Correspondence: guenter.langergraber@boku.ac.at; Tel.: +43-(0)1-47654-811-11
}

Citation: Handl, S.; Calheiros, C.S.C.; Fiebig, M.; Langergraber, G. Educational Resources for Geoethical Aspects of Water Management. Geosciences 2022, 12, 80. https:// doi.org/10.3390/geosciences12020080 Academic Editors: Marcos Mateus and Jesus Martinez-Frias

Received: 4 January 2022

Accepted: 4 February 2022

Published: 8 February 2022

Publisher's Note: MDPI stays neutral with regard to jurisdictional claims in published maps and institutional affiliations.

Copyright: () 2022 by the authors. Licensee MDPI, Basel, Switzerland. This article is an open access article distributed under the terms and conditions of the Creative Commons Attribution (CC BY) license (https:// creativecommons.org/licenses/by/ $4.0 /)$.

\begin{abstract}
Global water resources are a critical value for the future of humankind. Conflicts and wars seem to rise because of such critical resources. While water-scarce countries are under extreme pressure on the long-term scale, also water-rich countries in Europe, such as Austria, face local conflicts of interest between water supply, tourism, agriculture, hydropower and ecology, for instance. Higher Education must address these conflicts and the new concepts of geoethics offer the conceptional thinking to do so. Based on educational resources for Higher Education that have been developed in the field of "Geoethics and Water Management" under the Erasmus+ co-funded project GOAL (Geoethics Outcomes and Awareness Learning), selected water-related conflicts are discussed. The cases selected for developing the educational resources are water use conflicts and geoethical aspects of hydropower plants. The educational resources include a subsequent procedure for applying them with students. Outcomes from the educational resources show that issues related to water management often create geoethical conflicts and dilemmas, and an interconnection between several Sustainable Development Goals can be established. Applying the educational resources shall enable geoscientists to contribute towards sustainable development of Earth's future by a more holistic view.
\end{abstract}

Keywords: water resources; SDGs; higher education; case-based learning; geoethics; geosciences; conflicts of interest; virtual water

\section{Introduction}

Discussions on the impact of human activities on the Earth system led to scientific debate on the need for society to define a wiser, responsible, and sustainable way to assure life on Earth [1-3]. The effects of human activities on ecosystems have caused an overshoot of planetary boundaries in many cases. These human activities are caused by culturally defined, human world views, belief systems and values [4]. Environmental, social, and technical challenges, such as the loss of biodiversity or structural changes in society and technology, are the result of overshooting planetary boundaries. Ethical thinking towards the Earth system has been growing as a philosophical reflection in different cultures and historical moments for a very long time. As a result of ethical thinking, geoethics emerged as a new field of knowledge [5-7]. The lnternational Association for Promoting Geoethics (IAPG) [8] give the definition that geoethics "consists of research and reflection on the values which underpin appropriate behaviours and practices, wherever human activities interact with the Earth system. Geoethics deals with the ethical, social and cultural implications of geoscience education, research and practice, and with the social role and responsibility of geoscientists in conducting their activities". 
The cooperation with other scientific disciplines such as biology, zoology, ecology, agronomy and environmental sciences is essential for geoscientists [9]. To fully appreciate the complexity of contemporary human-environment relationships, social sciences also need to be incorporated [10]. After all, many of the societal issues relating to the planet are not only concerned with the scientific understanding but "... are about moral and aesthetic choices. They are about equity and ethics" [11]. Geoethics spans a continuum of concerns, including establishing clear and transparent professional codes of practice, global legal frameworks, and governance around global environmental problems. Thus, geoethics can be considered as a theoretical framework as well as approaches and behaviours to contribute in achieving the Sustainable Development Goals (SDGs) that have been presented as the Agenda 2030 by the United Nations (UN) in September 2015 [12,13].

The SDGs present a global political agenda, which addresses a range of social, economic, and environmental challenges [12]. Building upon the UN Millennium Development Goals (MDGs) [14], the 17 SDGs aim towards more sustainable lifestyles, economic patterns, and provision of ecosystem services. To evaluate the achievement of the SDGs, 169 targets and 230 individual indicators have been defined [12]. The SDGs clearly show that the indivisibility of economic prosperity, environmental sustainability, social progress, and effective democratic governance is the basis for sustainable development. Interactions between different targets result in numerous synergies and trade-offs between targets of one SDG and targets of other SDGs, respectively $[15,16]$.

Within the SDGs, water is addressed in SDG 6 to "Ensure availability and sustainable management of water and sanitation for all". Within SDG 6, 8 targets and 11 indicators have been defined [12]. Water is not in a static condition, there is a continuous and dynamic exchange between the Earth spheres with no starting or ending point for the water cycle [17]. The water cycle and its connections with lithosphere, atmosphere, biosphere and hydrosphere builds the basis for all life on this planet. It also represents the limited resources upon which humankind is developing. Thus, the field of water management is confronted with many stresses of high diversity. A lot of these water-related stresses result in ethical challenges and dilemmas. The interrelations of water-related aspects become clear also through the wide range of synergies and trade-offs that have been identified between SDG 6 and targets of other SDGs [15,18].

Within the international Erasmus+ co-funded project GOAL (Geoethics Outcomes and Awareness Learning) the main aim was to develop a geoethics syllabus and offer suggestions of educational resources that can be used in Higher Education to promote awareness-raising on ethical and social implications of geoscience knowledge, education, research, practice and communication, thus enhancing the quality and relevance of student knowledge, skills and competencies [19]. Educational resources have been developed from the point of view of the different expertise of the project participants: i.e., georisks, geoscience education, environmental sciences and engineering, geoparks, mining, geo- and palaeontological heritage, and informatics in education. The project results aim to help students and early-stage professional geoscientists to address ethical and social challenges in their profession.

In this paper, which is based on selected content of the eBook prepared within the GOAL project [19], we present educational resources for geoethical aspects of water management. Firstly, we present briefly the theoretical background on the relationship of water management to geoethics, and the importance of water-related aspects in achieving the SDGs (based on Handl et al. [20]). Secondly, we describe the background and the main content of the educational resources for two of these ethical challenges and dilemmas, i.e., "Water: a geoethical perspective on one of humanities most valuable resource" [21] and "Geoethical aspects of hydropower plants" [22].

\section{Material and Methods}

The theoretical educational framework that is based on the social constructivist theory for the geoethical educational resources developed in the GOAL project are described in 
Vasconcelos et al. [23]. Social constructivism [24], which requires an environment rich in social interactions as it relies on collaborative work and group discussions, forms the basis of GOAL's educational framework. This framework guided the development of the syllabus and educational resources whereby they are framed on an inquiry-based teaching approach. Based on the framework, GOAL's syllabus and educational resources were designed as Higher Education geoscience courses.

GOAL's syllabus [25] sets forth that students should have standard knowledge in Earth Sciences to be able to critically discuss geoethical issues. The material developed should facilitate improving the capacity of all geoscientists to think and act (geo)ethically. Case-based learning (CBL) methodology was applied: The starting points are dilemmas from real life that are formulated as a case and require the learners to collaborate. The requirement of prior knowledge for CBL enables the students to apply their previous knowledge with the new challenge and gain new knowledge.

By applying CBL methodology, educational resources have been developed employing a plurality of teaching strategies for the following fields [25]:

- Geoethics: foundations, definition, meaning and values

- Geoethics and Georisks

- Geoethics and Geoheritage

- Geoethics and Mining

- Geoethics and Water Management

- Geoethics in Education

Within the educational resources, hypothetical and real-life cases are presented, requiring previous knowledge, and questions to be answered are defined. Various educational methods ranging from field trips to group-discussions in the classroom are suggested to elaborate the topics in general and the questions in particular.

In the field "Geoethics and Water Management", two educational resources have been developed: the first one dealing with water use conflicts [21] and the second one with geoethical aspects of hydropower plants [22]. For both topics we describe the theoretical background and then the educational resources by briefly introducing the cases, naming the questions, and describing the procedure that should be followed to work on the questions. When preparing the material for the students, only Open Access material was selected as resources required for preparation.

\section{Results and Discussion}

\subsection{Geoethical Aspects of Water Management}

\subsubsection{Geoethical Aspects of Water Management}

Water is the basis for life on Earth. Being a limiting resource for development, water has to be managed with care. Water management is subject to a wide range of stresses that result in ethical challenges and dilemmas [26]. In the GOAL project, the following water-related ethical challenges and dilemmas have been identified for issues related to water management [25]:

- Human right to water and the UN SDGs.

- Environmental justice related to water.

- Implications of climate change on water management.

- Competing interests of different stakeholders concerning water and land-use management.

- Coherent environmental policies as essential baseline to achieve societal goals related to water.

- Transnational implications of large water-infrastructure projects.

- $\quad$ Specificities related with groundwater management.

- Personal daily behaviours and the influence on water consumption. 


\subsubsection{Importance of Water-Related Aspects in Achieving SDGs}

As water connects the lithosphere, atmosphere, biosphere and hydrosphere and is essential for life, there are numerous interrelations of the water related SDG 6 to other SDGs. Pradhan et al. [15] reported highest synergies with SDG 1 (No poverty) and SDG 3 (Good health and wellbeing). In 2015 the number of inhabitants from countries with high potential for synergies between SDG 3 and SDG 6 was reported to be approximately 2.7 billion. SDG 12 (Responsible consumption and production) was identified as the SDG with the highest trade-offs to SDG 6.

Groundwater systems are another example showing the interconnections. They are the planet's major storage reserve of freshwater and thus a critical buffer for socioeconomic adaptation to climate and environmental change. Over-usage of groundwater and the threat of groundwater depletion and quality degradation are not only affecting SDG 6 but also SDG 2 (Zero hunger) on food security, SDG 3 (Good health and wellbeing) on human health, SDG 11 (Sustainable cities and consumption) on resilient cities, and SDG-15 (Life on land) on protecting ecosystems and conserving biodiversity [27].

Requejo-Castro et al. [18] described interactions of SDG 6 indicators on indicators of other SGDs focussing on how SDG 6 impregnates the social, environmental and economic dimensions of sustainable development. First-order linkages are referred to as "direct" and second-order linkages are referred to as "indirect" (e.g., coupled via another SDG target) (Figure 1). Eight SDGs were linked directly to SDG 6. They identified direct linkages between SDG 6 indicators and indicators of other SGDs in relation to "Good health and wellbeing" (SDG 3), "Gender equality (SDG 5), "Affordable and clean energy" (SDG 7), "Decent work and economic growth" (SDG 8), "Reduced inequalities" (SDG 10), "Sustainable cities and consumption" (SDG 11), "Responsible consumption and production" (SDG 12), and "Life on land" (SDG 15). Additional five SDGs are connected to SDG 6 when considering "second order" (indirect) links, i.e., SDG 1 (No poverty), SDG 2 (Zero hunger), SDG 9 (Industry, innovation, and infrastructure), SDG 14 (Life below water), and SDG 16 (Peace, justice and strong institutions). However, the linkages presented by Requejo-Castro et al. [18] are lacking a few important linkages. Figure 1 thus includes important missing linkages, e.g., for Indicator 6.1.1. "Proportion of population using safely managed drinking water services", a direct link has been identified only to Indicator 7.1.1. "Proportion of population with access to electricity". However, the obvious direct linkage to Indicator 3.9.2. "Mortality rate attributed to unsafe water, unsafe sanitation and lack of hygiene" is missing. A direct link to Indicator 3.9.2. is only depicted for the indicator of the sanitation target, i.e., Indicator 6.2.1. "Proportion of population using safely managed sanitation services, including a hand-washing facility with soap and water". Additionally, for Indicator 6.3.1. "Proportion of domestic and ind ustrial wastewater flows safely treated "there is a direct link to Indicator 3.9.2.

Additionally, SDG 6-related synergies and trade-offs are described with focus on, for instance, the Water-Energy-Food Nexus [28,29], wetlands [30], water stress [31,32], water use efficiency [33], water quality [34,35], urban water management [36], ecosystem-based water security [37], and nature's contribution towards achieving SDG 6 [38].

In the project UniNEtZ (Universitäten und nachhaltige Entwicklungsziele-translation: Universities and Sustainable Development Goals) [39,40], 15 Austrian universities work together on developing options for achieving the SDGs in Austria. Even though SDG 14 ("Life below water") was not considered, about 150 options were identified for the 16 remaining SDGs. For SDG 6, 11 options have been developed. These options include topics like better access to public drinking water supply and sanitation facilities, implementation of resources-oriented sanitation and blue-green-brown infrastructure, measures to increase water efficiency, reduce diffuse pollution as well as reduce the use and discharge of micropollutants, etc. All options have been assessed regarding the possible synergies and trade-offs with SDG 6 targets and the targets of all other SDGs. 


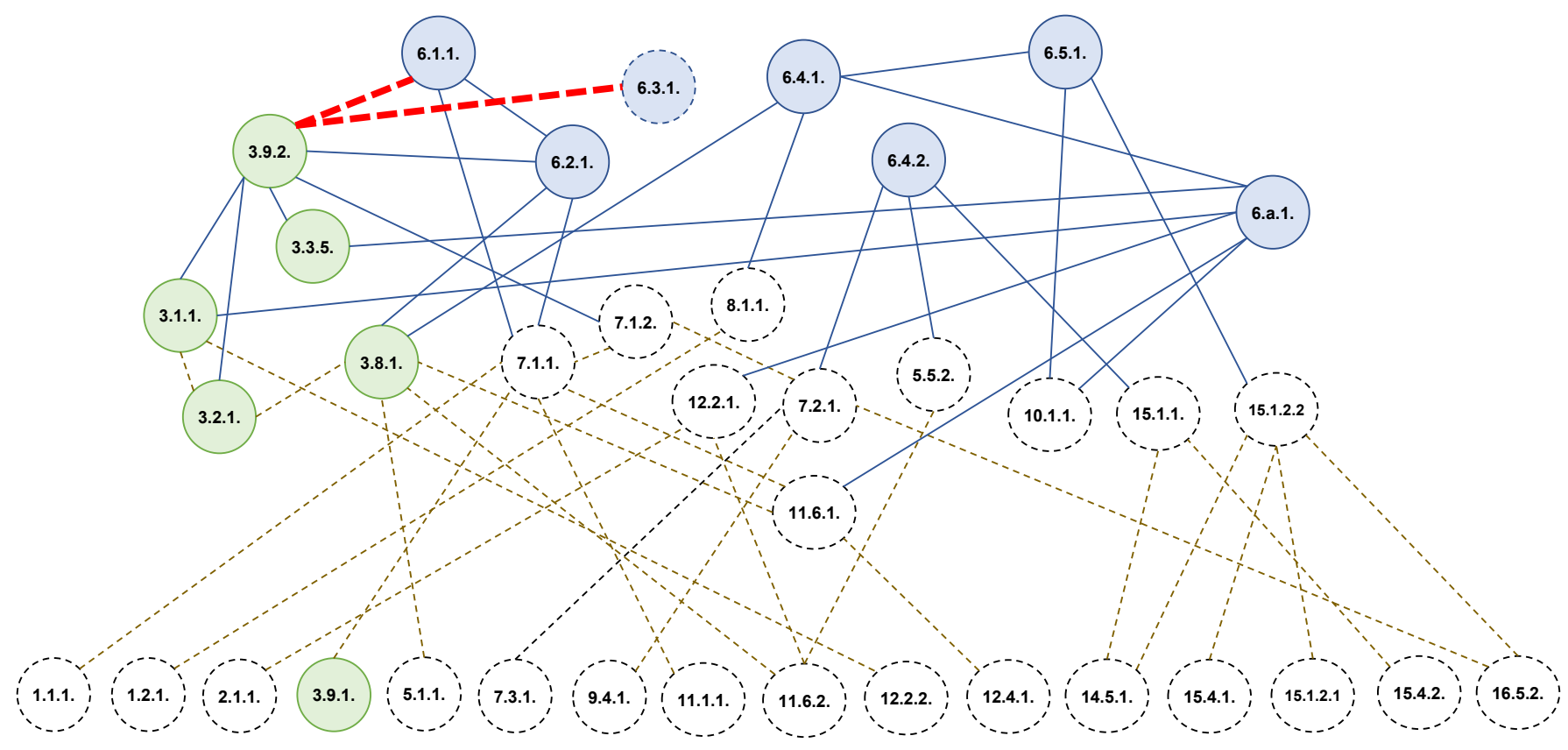

Figure 1. Interlinkages of SDGs to SDG 6 targets based on Requejo-Castro et al. [18] redrawn and modified by the authors. Solid blue lines indicate "First-order" (direct) linkages. Brown dotted lines indicate "Second-order" (indirect) relationships. Additional direct linkages are identified by thick dotted red lines. Blue circles represent SDG 6 targets, green circles SDG 3 targets, whereas white circles with dashed lines represent targets from all other SDGs.

\subsection{Educational Resources}

\subsubsection{A Geoethical Perspective on One of the Most Valuable Resources for Humanity}

In the first educational resource, water use conflicts are discussed. Firstly, we describe competing interests of different stakeholders concerning water and land-use management which are big drivers of conflicts. Secondly, the effect of personal behaviour on water and energy consumption is addressed [21].

\section{Theoretical Background}

Kaushal et al. [41] describe the wide range of interactions between water resources, land use and the climate on a global scale. The way weather and, on a longer timescale, also climate change interrelate with the quantity and distribution of water over time and space strongly depends on land use. The quality of water in surface and groundwater bodies is further connected to these influences. Humans strongly transform the earth surface via cultivation, agriculture, or urbanisation. These actions affect hydrological processes like the alteration of rainfall regimes (e.g., modification of urban areas) or evapotranspiration (e.g., irrigation in agriculture). Overland flow and runoff are increased due to reduction of permeable surface (sealing and compaction of soils). Groundwater quantity is affected due to alterations in recharge (reduced melting from snow covers, change in precipitation patterns) and increasing abstraction. Changes in hydrological processes affect aquatic ecosystems by altering their structure and function. These changes further influence associated services provided by the ecosystems that are connected to vulnerability to extreme weather events. Consequently, the changes in land management have significantly reduced the capacity with which aquatic ecosystems contribute to the resilience and resistance to climate change effects in water management [20].

Water management is facing qualitative issues, that sum up in the challenge of providing access to clean drinking water as well as challenges related to future quantitative issues (water scarcity: drought; excess of water: flooding). The effects of climate change are expected to further enhance these issues by increasing the dimension and frequency of weather extremes, especially for precipitation and temperature. Furthermore, the increasing 
discussion of ethics in water resource management reflects its increasing importance [17]. To reach the goals of rehabilitation of lost ecosystem services and mitigation of adverse effects, the process of deterioration of water ecosystems has to be considered. Adaptive management strategies should be implemented in Water management to increase flexibility towards expected increasing dynamics in the future. To decrease and/or reverse negative impacts and interactions between climate land use and water resources, it is essential to increase conservation of natural areas [20].

Moreover, one's personal water consumption leads to ethical conflicts and dilemmas. Sustainability of water consumption classically focuses on calculating budgets for ground and surface water by comparing withdraw and supply on the scale of catchment. To widen the perspective, the water footprint (WF) was introduced as a multidimensional indicator for fresh water use [42]. Within this framework, direct water refers to fresh water used directly for the considered product or process. Indirect water refers to water necessary for the production of materials and products used in the current process or product. Depending on the three possible sources, the water is categorised in types. Water from surface or groundwater bodies is labelled blue water. Water from precipitation and soil moister that does not contribute to groundwater nor runoff is labelled green water. Water pollution is accounted for by grey water. It refers to the necessary quantity of water to comply with quality standards depending on the substances released during production. The WF aims to widen awareness about the impacts that certain goods, consumers or groups have on types of freshwater as well as where and when these occur. It provides an important foundation for more detailed investigations about the magnitude of impacts by decisions and actions on the freshwater system, also considering its vulnerability to certain stresses. It provides a framework to assess environmental, social and economic implications. Furthermore, it builds a solid basis for the discussion of issues related to sustainability and equitability of the allocation and use of fresh water [43].

According to water types, three WF types are distinguished [44]:

1. Green WF comprises water from precipitation that is stored in the root zone of the soil and evaporated, transpired or incorporated by plants. It has high relevance for food production (agriculture and horticulture) and forestry.

2. Blue WF comprises water that has been sourced from surface or groundwater resources and is either evaporated, incorporated into a product or taken from one body of water and returned to another, or returned at a different time. Irrigated agriculture, industry and domestic water use are traditional sectors with large blue water footprints.

3. Grey WF comprises the amount of fresh water required to assimilate pollutants to meet specific water quality standards. Considered forms of contamination include pointsources (e.g., discharge to groundwater of surface water directly) or indirect sources (e.g., runoff or leaching from soils or impermeable surfaces, or other diffuse sources). The global average annual WF of 9087 billion $\mathrm{m}^{3}$ per year, for the period 1996-2005, is comprised of $74 \%$ Green, 11\% Blue and the remaining 15\% Grey WF. In total WF, contribution by sectors is very different. Agriculture uses by far the biggest amount (92\%). Industry $(4.4 \%)$ and domestic water supply (3.6\%) account for much lower proportions. International transport of virtual water, i.e., the amount of water required for the production of a product or for a service, accounts for a quarter of the total WF, on average. Approximately $50 \%$ of the international Blue WF originates from only seven nations which face water stress at least partly. The biggest export countries for net virtual water are the USA, Brazil, Argentina, India and Australia. Globally, North Africa, the Middle East, Mexico, Europe, Japan and South Korea are the most relevant net importers for virtual water [42].

On a national level, the per capita water consumption is strongly influenced by the amount and type of goods consumed and further by the conditions under which they were produced. The authors report values between $550-3800 \mathrm{~m}^{3}$ per year and capita (i.e., 1500-10,400 L per day and capita) for all countries with a population above 5 million. 
For developed countries the range spans from $1250-2850 \mathrm{~m}^{3}$ per year and capita (i.e., 3400-7800 L per day and capita) [42].

A recent study from Austria reported a daily per capita water consumption of $4740 \mathrm{~L}$ compared to a direct water consumption of $126 \mathrm{~L}$ per day and capita in households (Table 1). Food consumed is responsible for the major part of the WF. It is prognosed that the per capita water consumption in 2050 will be rising up to between 5000 and $5310 \mathrm{~L}$. The study concluded that food production is mainly responsible for the increase of the WF over time [45].

Table 1. Water consumption per day and capita in Austria. Data in L per capita per day [45].

\begin{tabular}{cccc}
\hline Water Consumption & $\begin{array}{c}\text { Published Values [46] } \\
\text { (Based on 2005 Data) }\end{array}$ & $\begin{array}{c}\text { Current Values } \\
\text { (Based on 2018 Data) }\end{array}$ & Prognoses for 2050 \\
\hline Direct water consumption in households & 114 & 126 & $236-242 *$ \\
Other direct water consumption & Not reported & 108 & $1746-1762$ \\
Food-plant products & 1570 & 1630 & $2033-2325$ \\
Food-animal products & 1729 & 1890 & 376 \\
Non-edible agricultural products & 356 & 376 & 608 \\
Other products & 608 & 608 & $4999-5314$ \\
\hline Total & 4377 & 4738 & \\
\hline
\end{tabular}

* only total value of direct water consumption given.

Since food production was identified as the main contributor to the WF, the study also proposed the following three potentials for lowering the WF [45]:

1. Food losses: Food losses account for $500 \mathrm{~L}$ per day and capita, in total, whereby $280 \mathrm{~L}$ per day and capita occur in households.

2. Consumer behaviour: It can be expected that if more regional-produced products are consumed, the WF will decrease. Mainly due to climatic boundary conditions, water consumption to produce crops in Austria is generally lower compared to imported goods.

3. Dietary changes: Comparing the actual diet in Austria (that results in $3300 \mathrm{~L}$ per day and capita) and recommendations for healthy diet (that results in 1900-2350 L per day and capita) shows that the biggest reduction of the WF can be obtained here.

Case and Approach for Educational Resource

The case is built on the Vienna water supply. A student group follows an excursion along the water mains, i.e., the main transport pipes for water from the sources over more than $100 \mathrm{~km}$ to Vienna. The group first visits the Kaiserbrunn spring (Figure 2, left), located at the first Vienna water main that was established in 1873. In 1910, the second Vienna water main was put into operation, wherein the Kläfferquelle spring (Figure 2, right) is one of the largest karstic springs in Europe [21].

In Kaiserbrunn, the student group visits the water museum and a staff member of the Vienna water works discusses with them the main challenges connected to managing the catchment area of the springs, i.e., forestry and optimizing its management, tourism, and agriculture (mainly pasture of cattle). At their second stop the students visit the Kläfferquelle that is established as an educational site belonging to the UNESCO Global Geopark "Steirische Eisenwurzen", which is member of the European Geoparks Network. At the site, information on the hydrogeological background as well as on the history of the capturing of the spring is available [21]. 

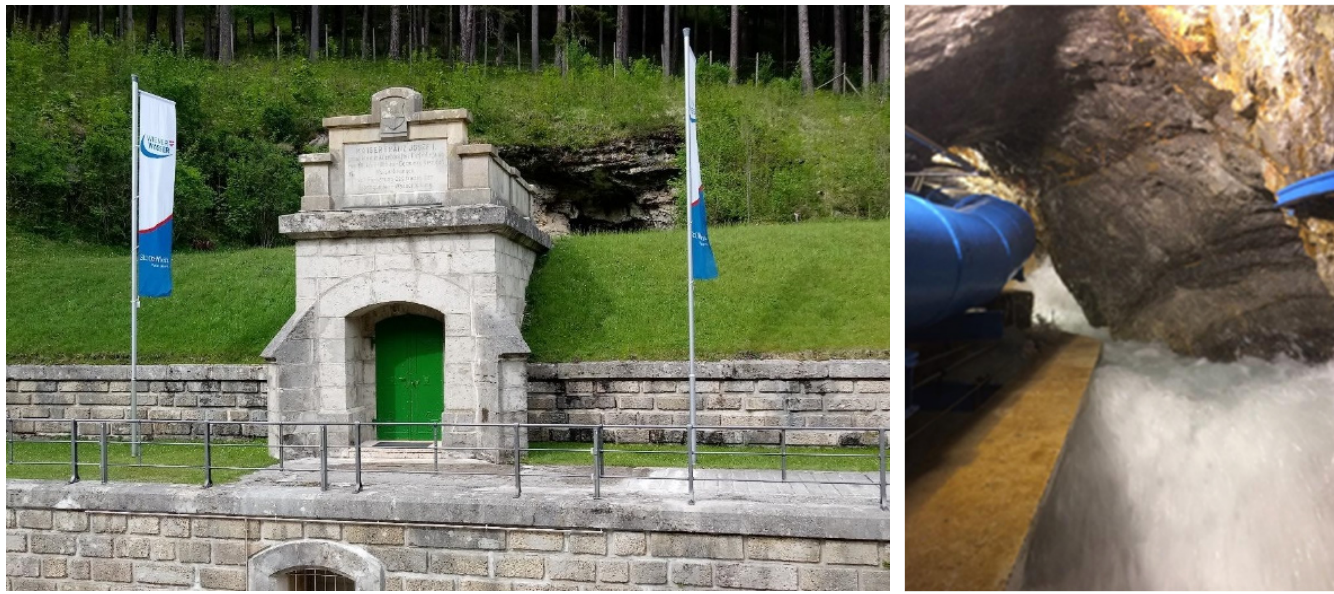

Figure 2. Entrance to the Kaiserbrunn spring (left) and view of the opening of the Kläfferquelle spring in the mountain (right) [21].

During the drive back from the sites, a video is circulated among the students that concerns water management on a global scale and explains the Water Footprint concept. The impressions of the day inspire a lively discussion between the students around the topics of water management from local to global scale. Within the group, the relevant questions raised were [21]:

1. Which geoethical issues and dilemmas arise from different interests in land use in this (and other) catchment area(s) of springs?

2. What would happen if the land would not be in possession of the Vienna Water Works and the landowner would decide to change the forestry strategy (for example, towards maximization for wood production or implementing agriculture)?

3. How can geoethical values be met by the operation and management of the catchment area of the springs?

4. Which geoethical values are met by the Water Footprint Network?

5. Which SDGs have a strong impact on water supply management and may also pose a (partial) conflict of interest to SDG 6?

6. Which geoethical issues and dilemmas are related to the achievement of the different SDGs and what is their linkage?

7. How can Earth Scientists be involved in the process of achieving the SDGs related to water management?

8. Explain how geoethical values support geoscientists in their role in the process of achieving the SDGs.

The proposed procedure for applying the educational resource in the class room comprises the following steps (in groups of $4-5$ students) [21]:

1. To make the students familiar with Vienna's water supply, students should watch two online videos: "Vienna's Water short" [47] and "Kläfferquelle-Some facts about the big karstic spring" [48]. After becoming familiar with geoethical dilemmas [49], they should answer questions 1 and 2 in the groups. Afterwards the answers to all the questions are collected from all groups and discussed in a plenary session.

2. After becoming further familiar with social and cultural values in geoethics [6], question 3 should be answered by each student individually.

3. The next step requires becoming familiar with the water footprint [50,51]; each student estimates her/his direct and virtual water consumption of the day (starting from breakfast, showering, consumption of goods, etc.) by writing down her/his direct and virtual water consumption. Afterwards, question 4 should be answered in the groups already established; answers from all groups are then discussed in a plenary session.

4. For questions 5 and 6, students need to become familiar with the UN SDGs [12], then each group selects 3 SDGs (covering all SDGs during consideration for selection for 
answering these questions. Again, answers from all groups are discussed in a plenary session. The final plenary discussion focuses on how geoethical values and principles can support the achievement of sustainable development.

More details on the case and the procedure can be found in the full educational resource [21].

\subsubsection{Geoethical Aspects of Hydropower Plants}

In the second educational resource, geoethical aspects of hydropower plants are discussed. Global warming, as a key challenge, underscores the importance of producing energy from renewable resources, which also fosters future development and further influences many other SDGs. Hydropower, on the one hand, meets these requirements (e.g., free of greenhouse gases) but, on the other hand, the structures that are necessary (e.g., dams) strongly affect aquatic ecosystems [22].

\section{Theoretical Background}

Significant interventions on aquatic ecosystems date back to medieval and even ancient times [52,53]. During industrialization, changes intensified fuelled by fossil energy production with strong effects on river morphology, hydrological regime and aquatic biota, with unprecedented consequences on ecology. Further economic and technological developments well into the twentieth century resulted in increasing stresses to the aquatic ecosystems from increasing automatization in industry and households, intensified exploitation of resources, and the use of heavy machinery and substances (e.g., fertilizers, pesticides) in agriculture. The results were a strong decrease of water quality as well as hydro-morphological factors [54].

Energy from hydropower is perceived "green" but the structures that facilitate its production (especially dams) cause several significant impacts to ecosystems of rivers and alter the functions they can provide. The influences on river ecology comprise the following main aspects [55]:

- Flow in rivers: The shape, size and structure of a river are strongly defined by its flow regime and so is the dynamic of the ecosystem within the river. The river flow strongly depends on the hydrological regime and forms the habitats for the biotic communities. Anthropogenic influences like water abstraction (irrigation), channelization of the river course, dams (hydropower) and land use yield significant effects on river flows. Climate change will further affect river ecosystems [56].

- Dams and reservoirs: Dams and Reservoirs that are built for specific community needs (e.g., water supply, hydropower generation, agricultural irrigation, river regulation and flood control, etc.) have the following main impacts on rivers: interruption of river continuity; siltation of river bed and interstitial clogging; homogenization of habitats; alteration of river/groundwater exchange; and alteration of downstream flow and water quality [57].

- $\quad$ Sediment transport: Sediment transport, besides by river flow, is severely altered by dams. The functions of sediments range from a morphological feature that determines the hydraulic patterns of a river to being habitat for aquatic biota (e.g., macroinvertebrates, fish). River management needs to holistically manage river systems regarding the driving abiotic processes including sediment management and include the responsible actors like water management authorities as well as hydropower companies [58,59].

- Hydropeaking: Due to the operation of hydropower plants during high demands of energy, artificial flow fluctuations occur downstream. This effect is called hydropeaking and it strongly affects the survival and reproductive potential of aquatic organisms. Organisms are generally adapted to natural dynamics in discharge, however, hydropeaking results in often exceptionally high intensity and/or unusual event timing. Human actives thus induce harmful impacts on aquatic ecology [60]. 
- River connectivity: Interactions and exchanges between terrestrial and homogenous habitat patches defined river connectivity for a long time. Internal structure and heterogeneity have often been neglected [61]. Hydropower regulation is a main reason for fragmentation of rivers and thus the decline and reduced distribution of freshwater fishes. The knowledge-based approach of sustainable hydropower production aims to mitigate these impacts and to resolve or avoid the potential conflicts between energy production and aquatic ecosystems. [62].

Additional aspects related to hydropower for potential conflicts and dilemmas are:

- Hydropower and People: Direct impact on people is visible if villages or even whole cities are flooded for new reservoir projects. The construction of large dams led to the resettlement of up to 80 million people in the past century, approximately 1.3 million of which only for the Three Gorges Dam in China alone. [63].

- Socio-environmental conflicts related to dams and hydropower: Socio-environmental conflicts can be categorised in: (1) Control over the use of natural resources; (2) Environmental and social impacts created by human and natural activity; and (3) Use of environmental knowledge but on sacred or spiritual sites [64-66]. In the case of transboundary rivers, severe conflicts can also occur between states. A recent example being the Grand Ethiopian Renaissance Dam on the Nile River [67]. Underlying conflicts (e.g., unequal access to resources, land use patterns, etc.) can cause them. However, treatment, handling or management of different interests (e.g., governance schemes, participation processes) can be the root of the conflict $[66,68]$.

With approximately six dams per $100 \mathrm{~km}^{2}$, Austria is one of the countries with the highest density of hydropower dams. From the over 5200 hydropower plants that are operated in Austria alone, only $6 \%$ produce over $88 \%$ of the total capacity. A large number of small rivers are affected by the huge number of small hydropower plants in Austria [69].

\section{Case and Approach for Educational Resource}

The case is built around a group of students from Vienna that go for a rafting and kayaking weekend. The location chosen is the pristine Salza river, an eastern tributary of the Enns river, that is a popular spot for water sports (rafting, kayaking, etc.). Most water sport activities start downstream of the Prescenyklause (Figure 3) that was constructed in 1848 as a small dam for a saw mill. In the 1980s, the Prescenyklause was re-adapted as a hydropower plant with approximately $1.5 \mathrm{MW}$ of power [22].
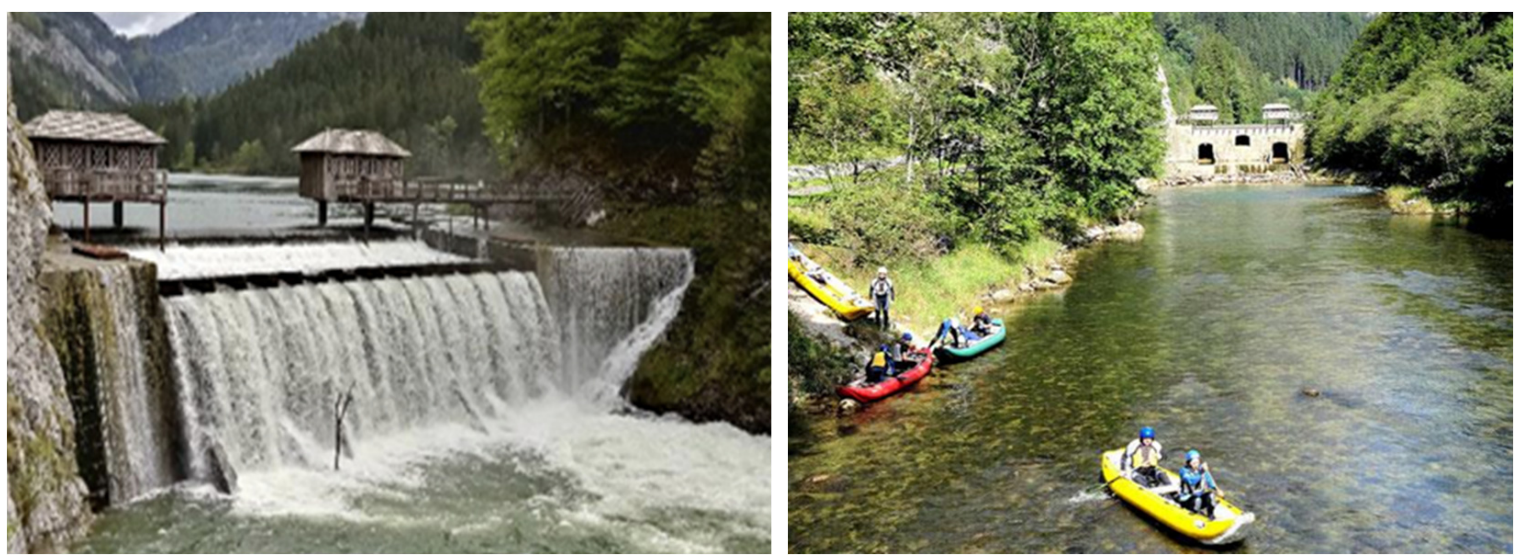

Figure 3. Below the Prescenyklause (left) is the starting point of kayaking tours (right) [22].

The group of students enjoyed the nice scenery of the Salza river. However, when they reached the starting point of their first kayak tour downstream from the Prescenyklause, the massive construction of the Klause raised questions on its impact on the Salza river. The following questions have been stipulated to be raised by the group [22]: 
1. What are the general impacts of dams on riverine ecosystems?

2. What are the stakeholders to be involved in the planning of a hydropower plant?

3. What geoethical conflicts and dilemmas are linked to hydropower plants, e.g., in terms of sustainability, "green" thinking and environmental impact?

4. Can all conflicts be solved to satisfy all stakeholders? How?

5. What technical measures can be implemented at sites with hydropower plants in general and at the Prescenyklause in particular to improve the riverine ecosystem?

6. How can we deal with the resulting dilemmas?

7. How can we sustainably preserve water so future generations can benefit from this natural resource?

The procedure for applying the educational resource to students in the class room comprises a preparation phase and group work. During preparation, students should become familiar with principles of geoethics [2], geoethical dilemmas [49] and the effect of hydropower on rivers (selected chapters from [55]). Afterwards, each student should write down keywords on his/her spontaneous mental connections with the "rivers" and "dams". Based on these keywords, groups discuss the relationship between humans and rivers. Finally, questions 1 through 6 should be elaborated in small groups; after each question results are presented and discussed to allow each group to have the same starting point for the next question.

Again, more details on the case and the procedure can be found in the full educational resource [22].

\section{Conclusions}

From the results presented in this study, the following general conclusions can be drawn:

- Water-related challenges are deeply interwoven in the network of dependencies between the different Sustainable Development Goals, especially with the targets defined in SDG 6 "Ensure availability and sustainable management of water and sanitation for all". Managing water accordingly is key to reaching many targets in other SDGs as well.

- Water has a strong interconnecting nature; it's a precious resource for humans and all organisms alike. These properties explain the multiple stresses on water management which result in numerous ethical challenges and dilemmas in this field. Consequently, working in the field of water management requires knowledge about ethical issues and dilemmas. Thus, in water management, the principles of geoethical thinking already have been considered for a long time.

- Due to the interconnecting nature of water, issues related to water management often create geoethical conflicts and dilemmas.

From the geoethical conflicts and dilemmas used as a basis for developing the educational resources, the main take-home messages are:

- Well managed drinking water supplies should benefit society by providing drinking water with low costs and also should focus on resource resilience, and therefor maintaining intact ecosystems. Water supplies in the public domain more likely guarantee these aspects, since they are run in a less profit-driven way and are focused on the long-term functioning of the water supply system.

- In the global north, our water demand is significantly higher than the direct water consumption of a person. Water consumed virtually, i.e., that was used to produce other goods such food or cloth, greatly exceeds direct water consumption. Concepts such as water footprint are vital to illustrating and illuminating these connections as a first step towards ending unsustainable practices. Knowing these concepts enables graduates from geosciences to raise awareness or analyse different issues with similar tools.

- Sustainable energy production not only has to take greenhouse gas emissions into account, but also ecology and the potential of socio-environmental conflicts. In the case 
of hydropower plants, a wide range of possible issues have to be considered as connected to topics such as ecosystem services, habitat conditions, resource accessibility and / or religion and culture.

Finally, the educational materials developed within the GOAL project in the field "Geoethics and Water Management" will allow that geoethical topics in general can be included more easily in higher education. The cases for which the educational resources have been developed, i.e., water use conflicts and geoethical aspects of hydropower plants, are typical geoethical conflicts and dilemmas arising in water management; thus, they are suitable for an introduction to the field of "Geoethics and Water Management".

Only when holistic thinking becomes mainstream and common practice in all fields will it be possible to reach the targets of the SDGs; only thus will a transformation towards sustainable development be possible. Graduates of higher education institutions for geosciences that will become professionals in this field will play an important role in the process of achieving these adaptations in society. They will support the way towards the mitigation of adverse consequences, while also adapting to effects that are not reversible.

Geoethical thinking can contribute towards this more holistic view on Earth's future. The relationships between our actions and different ecosystems are very complex; often, one single solution that can provide only benefits does not exist. This will consequently result in ethical challenges and dilemmas. Professionals in the field of geosciences will more and more need to know how to deal with such situations. The field of Geoethics engages with these questions. It provides the toolbox in the form of a theoretical framework and vocabulary to describe the underlying problems. Consequently, geoethical education should play an important part in the training of all geoscientists.

Author Contributions: S.H. and G.L.: overall conceptualization, writing, illustrations, and reviewing: C.S.C.C. and M.F.: contribution to specific (sub)chapters and reviewing. All authors have read and agreed to the published version of the manuscript.

Funding: The work has been co-funded by the Erasmus+ project GOAL (Geoethics Outcomes and Awareness Learning: 2017-1-PTO1-KA203-035790; duration January 2018-August 2020).

Institutional Review Board Statement: Not applicable.

Informed Consent Statement: Not applicable.

Data Availability Statement: Not applicable.

Acknowledgments: This work has been carried out in the scope of Erasmus+ co-funded project GOAL (Geoethics Outcomes and Awareness Learning; reference: 2017-1-PTO1-KA203-035790; duration January 2018-August 2020). The authors are grateful for the support. C.S.C. Calheiros acknowledges the support of FCT-Foundation for Science and Technology within the scope of UIDB/04423/2020 and UIDP/04423/2020.

Conflicts of Interest: The authors declare no conflict of interest.

\section{References}

1. Otto, I.M.; Donges, J.F.; Cremades, R.; Bhowmik, A.; Hewitt, R.J.; Lucht, W.; Rockström, J.; Allerberger, F.; McCaffrey, M.; Doe, S.S.P.; et al. Social tipping dynamics for stabilising Earth's climate by 2050. Proc. Natl. Acad. Sci. USA 2020, 117, $2354-2365$. [CrossRef] [PubMed]

2. Peppoloni, S.; Bilham, N.; Di Capua, G. Contemporary Geoethics within Geosciences. In Exploring Geoethics—Ethical Implications, Societal Contexts, and Professional Obligations of the Geosciences; Bohle, M., Ed.; Palgrave Pivot: Cham, Switzerland, 2019; pp. 25-70. [CrossRef]

3. Vasconcelos, C.; Ferreira, F.; Rolo, A.; Moreira, B.; Melo, M. Improved Concept Map-Based Teaching to Promote a Holistic Earth System View. Geosciences 2020, 10, 8. [CrossRef]

4. Steffen, W.; Richardson, K.; Rockströöm, J.; Cornell, S.E.; Fetzer, I.; Bennett, E.M.; Biggs, R.; Carpenter, S.R.; De Vries, W.; De Wit, C.A.; et al. Planetary boundaries: Guiding human development on a changing planet. Science 2015, 347, 1259855. [CrossRef] [PubMed]

5. Wyss, M.; Peppoloni, S. Geoethics: Ethical Challenges and Case Studies in Earth Sciences; Elsevier: Amsterdam, The Netherlands, 2014; 450p, ISBN 978-0127999357. 
6. Peppoloni, S.; Di Capua, G. Geoethics: Ethical, Social, and Cultural Values in Geosciences Research, Practice, and Education. In Geoscience for the Public Good and Global Development: Toward a Sustainable Future; Wessel, G.R., Greenberg, J.K., Eds.; Geological Society of America: Boulder, CO, USA, 2016; pp. 17-23. [CrossRef]

7. Bobrowsky, P.; Cronin, V.S.; Di Capua, G.; Kieffer, S.W.; Peppoloni, S. The Emerging Field of Geoethics. In Scientific Integrity and Ethics with Applications to the Geosciences; Gundersen, L.C., Ed.; John Wiley and Sons: Hoboken, NJ, USA, 2017.

8. Di Capua, G.; Peppoloni, S. International Association for Promoting Geoethics. Defining Geoethics. 2019. Available online: https:/ / www.geoethics.org/definition (accessed on 18 December 2021).

9. Stewart, I. Sustainable geoscience. Nat. Geosci. 2016, 9, 262. [CrossRef]

10. Bohle, M. Exploring Geoethics-Ethical Implications, Societal Contexts, and Professional Obligations of the Geosciences; Palgrave Pivot: Cham, Switzerland, 2019; Volume 14, 214p, ISBN 978-3-030-12009-2.

11. Oreskes, N. Science and public policy: What's proof got to do with it? Environ. Sci. Policy 2004, 7, 369-383. [CrossRef]

12. United Nations. Transforming Our World: The 2030 Agenda for Sustainable Development. 2015. Available online: http://www.un. org/ga/search/view_doc.asp?symbol=A/RES/70/1\&Lang=E (accessed on 18 December 2021).

13. United Nations. Sustainable Development Goals Knowledge Platform. 2015. Available online: https://sustainabledevelopment. un.org/ (accessed on 18 December 2021).

14. United Nations. Millennium Development Goals. 2000. Available online: https://www.un.org/millenniumgoals / (accessed on 18 December 2021).

15. Pradhan, P.; Costa, L.; Rybski, D.; Lucht, W.; Kropp, J.P. A Systematic Study of Sustainable Development Goal (SDG) Interactions. Earth's Future 2017, 5, 1169-1179. [CrossRef]

16. Biggeri, M.; Clark, D.A.; Ferrannini, A.; Mauro, V. Tracking the SDGs in an 'integrated' manner: A proposal for a new index to capture synergies and trade-offs between and within goals. World Dev. 2019, 122, 628-647. [CrossRef]

17. United Nations Educational, Scientific and Cultural Organization. Water Ethics and Water Resource Management; Working Group 14 Report, Ethics and Climate Change in Asia and the Pacific (ECCAP) Project; United Nations Educational, Scientific and Cultural Organization: Bangkok, Thailand, 2011; ISBN 978-92-9223-359-4.

18. Requejo-Castro, D.; Giné-Garriga, R.; Pérez-Foguet, A. Data-driven Bayesian network modelling to explore the relationships between SDG 6 and the 2030 Agenda. Sci. Total Environ. 2020, 710, 136014. [CrossRef] [PubMed]

19. Vasconcelos, C.; Schneider-Voss, S.; Peppoloni, S. Teaching Geoethics—Resources for Higher Education; Universidade do Porto: Porto, Portugal, 2020; 207p, ISBN 978-989-746-254-2. [CrossRef]

20. Handl, S.; Schneider-Voss, S.; Fiebig, M.; Calheiros, C.S.C.; Langergraber, G. Geoethics and Water Management. In Teaching Geoethics-Resources for Higher Education; Vasconcelos, C., Schneider-Voss, S., Peppoloni, S., Eds.; Universidade do Porto: Porto, Portugal, 2020; pp. 83-96, ISBN 978-989-746-254-2. [CrossRef]

21. Handl, S.; Langergraber, G.; Schneider-Voss, S.; Fiebig, M. Water: A Geoethical Perspective on One of the Humanities Most Valuable Resource. In Teaching Geoethics—Resources for Higher Education; Vasconcelos, C., Schneider-Voss, S., Peppoloni, S., Eds.; Universidade do Porto: Porto, Portugal, 2020; pp. 187-191, ISBN 978-989-746-254-2. [CrossRef]

22. Langergraber, G.; Handl, S.; Schneider-Voss, S.; Fiebig, M. Geoethical Aspects of Hydropower Plants. In Teaching GeoethicsResources for Higher Education; Vasconcelos, C., Schneider-Voss, S., Peppoloni, S., Eds.; Universidade do Porto: Porto, Portugal, 2020; pp. 182-188, ISBN 978-989-746-254-2. [CrossRef]

23. Vasconcelos, C.; Ribeiro, T.; Cardoso, A.; Orion, N.; Ben-Shalom, R. Educational Theoretical Framework Underpinning Geoethical Educational Resources. In Teaching Geoethics—Resources for Higher Education; Vasconcelos, C., Schneider-Voss, S., Peppoloni, S., Eds.; Universidade do Porto: Porto, Portugal, 2020; pp. 19-29, ISBN 978-989-746-254-2. [CrossRef]

24. Detel, W. Social Constructivism. In International Encyclopedia of the Social \& Behavioral Sciences; Smelser, N.J., Baltes, P.B., Eds.; Pergamon Press: Oxford, UK, 2001; pp. 14264-14267. [CrossRef]

25. Vasconcelos, C.; Azana, B.; Ben Shalom, R.; Brilha, J.; Calheiros, C.S.C.; DeMiguel, D.; Di Capua, G.; Langergraber, G.; Lima, A.; Meléndez, G.; et al. GOAL Geoethics Syllabus. In Teaching Geoethics-Resources for Higher Education; Vasconcelos, C., Schneider-Voss, S., Peppoloni, S., Eds.; Universidade do Porto: Porto, Portugal, 2020; pp. 141-147, ISBN 978-989-746-254-2. [CrossRef]

26. Marone, E.; Peppoloni, S. Ethical dilemmas in geosciences. We can ask, but, can we answer? Ann. Geophys. 2017, 60, 7. [CrossRef]

27. Bhaduri, A.; Bogardi, J.; Siddiqi, A.; Voigt, H.; Vörösmarty, C.; Pahl-Wostl, C.; Bunn, S.E.; Shrivastava, P.; Lawford, R.; Foster, S.; et al. Achieving Sustainable Development Goals from a Water Perspective. Front. Environ. Sci. 2016, 4, 64. [CrossRef]

28. Kurian, M.; Scott, C.; Reddy, V.R.; Alabaster, G.; Nardocci, A.; Portney, K.; Boer, R.; Hannibal, B. One Swallow Does Not Make a Summer: Siloes, Trade-Offs and Synergies in the Water-Energy-Food Nexus. Front. Environ. Sci. 2019, 7, 32. [CrossRef]

29. Fader, M.; Cranmer, C.; Lawford, R.; Engel-Cox, J. Toward an Understanding of Synergies and Trade-Offs Between Water, Energy, and Food SDG Targets. Front. Environ. Sci. 2018, 6, 112. [CrossRef]

30. Jaramillo, F.; Desormeaux, A.; Hedlund, J.; Jawitz, J.W.; Clerici, N.; Piemontese, L.; Rodríguez-Rodriguez, J.A.; Anaya, J.A.; Blanco-Libreros, J.F.; Borja, S.; et al. Priorities and Interactions of Sustainable Development Goals (SDGs) with Focus on Wetlands. Water 2019, 11, 619. [CrossRef]

31. Vanham, D.; Hoekstra, A.Y.; Wada, Y.; Bouraoui, F.; de Roo, A.; Mekonnen, M.M.; van de Bund, W.J.; Batelaan, O.; Pavelic, P.; Bastiaanssen, W.G.M.; et al. Physical water scarcity metrics for monitoring progress towards SDG target 6.4: An evaluation of indicator 6.4.2 "Level of water stress". Sci. Total Environ. 2018, 613-614, 218-232. [CrossRef] 
32. Fehri, R.; Khlifi, S.; Vanclooster, M. Disaggregating SDG-6 water stress indicator at different spatial and temporal scales in Tunisia. Sci. Total Environ. 2019, 694, 133766. [CrossRef]

33. Hellegers, P.; van Halsema, G. SDG indicator 6.4.1 "change in water use efficiency over time": Methodological flaws and suggestions for improvement. Sci. Total Environ. 2021, 801, 149431. [CrossRef]

34. Alcamo, J. Water quality and its interlinkages with the Sustainable Development Goals. Curr. Opin. Environ. Sustain. 2018, 36, 126-140. [CrossRef]

35. Flörke, M.; Bärlund, I.; van Vliet, M.T.H.; Bouwman, A.F.; Wada, Y. Analysing trade-offs between SDGs related to water quality using salinity as a marker. Curr. Opin. Environ. Sustain. 2018, 36, 96-104. [CrossRef]

36. Sørup, H.J.D.; Brudler, S.; Godskesen, B.; Dong, Y.; Lerer, S.M.; Rygaard, M.; Arnbjerg-Nielsen, K. Urban water management: Can UN SDG 6 be met within the Planetary Boundaries? Environ. Sci. Policy 2020, 106, 36-39. [CrossRef]

37. Vörösmarty, C.J.; Osuna, V.R.; Cak, A.D.; Bhaduri, A.; Bunn, S.; Corsi, F.; Gastelumendi, J.; Green, P.; Harrison, I.; Lawford, R.; et al. Ecosystem-based water security and the Sustainable Development Goals (SDGs). Ecohydrol. Hydrobiol. 2018, 18, 317-333. [CrossRef]

38. Mulligan, M.; van Soesbergen, A.; Hole, D.G.; Brooks, T.M.; Burke, S.; Hutton, J. Mapping nature's contribution to SDG 6 and implications for other SDGs at policy relevant scales. Remote Sens. Environ. 2020, 239, 111671. [CrossRef]

39. Körfgen, A.; Förster, K.; Glatz, I.; Maier, S.; Becsi, B.; Meyer, A.; Kromp-Kolb, H.; Stötter, J. It's a Hit! Mapping Austrian Research Contributions to the Sustainable Development Goals. Sustainability 2018, 10, 3295. [CrossRef]

40. UniNEtZ. Universitäten und Nachhaltige Entwicklungsziele. 2021. Available online: https://www.uninetz.at/en/ (accessed on 18 December 2021).

41. Kaushal, S.; Gold, A.; Mayer, P. Land Use, Climate, and Water Resources-Global Stages of Interaction. Water 2017, 9 , 815. [CrossRef] [PubMed]

42. Hoekstra, A.Y.; Mekonnen, M.M. The water footprint of humanity. Proc. Natl. Acad. Sci. USA 2012, 109, 3232-3237. [CrossRef] [PubMed]

43. Hoekstra, A.Y.; Chapagain, A.K.; Aldaya, M.M.; Mekonnen, M.M. The Water Footprint Assessment Manual: Setting the Global Standard; Earthscan: London, UK, 2011. Available online: https://waterfootprint.org/media/downloads/ TheWaterFootprintAssessmentManual_2.pdf (accessed on 18 December 2021).

44. SABMiller; World Wide Fund for Nature. Water Footprinting-Identifying $\mathcal{E}$ Addressing Water Risks in the Value Chain; SABMiller, World Wide Fund for Nature: Surrey, UK, 2009. Available online: https:/ /waterfootprint.org/media/downloads/SABMillerWWF-2009-waterfootprintingreport_1.pdf (accessed on 18 December 2021).

45. Bundesministerium für Landwirtschaft, Regionen und Tourismus; Österreichische Vereinigung für das Gas und Wasserfach. Virtuelles Wasser 2021. Wasserfußabdruck—der Wasserverbrauch für Güter des täglichen Bedarfs (Virtual Water 2021. Water FootprintThe Water Consumption for Goods of Daily Use); Austrian Federal Ministry of Agriculture, Regions and Tourism, and Austrian Association for the Gas and Water Industry: Vienna, Austria, 2021. Available online: https:/ /info.bmlrt.gv.at/themen/wasser/ foerderungen/virtuelles-wasser-wasserfussabdruck.html (accessed on 18 December 2021).

46. Vanham, D. The water footprint of Austria for different diets. Water Sci. Technol. 2013, 67, 824-830. [CrossRef]

47. City of Vienna. Vienna's Water Short. 2014. Available online: https:/ /www.wien.gv.at/video/403/Viennas-Water-short (accessed on 18 December 2021)

48. GOAL. Video Pill: Kläfferquelle—Some Facts about the Big Karstic Spring. 2020. Available online: https://youtu.be/qFwfniq5J78 (accessed on 18 December 2021).

49. GOAL. Video Pill: Geoethics Issues and Geoethical Dilemmas. 2020. Available online: https://www.youtube.com/watch?v= 1KBFAqMMnpo2020 (accessed on 18 December 2021).

50. Water Footprint Network. 2020. Available online: https://waterfootprint.org/en/ (accessed on 18 December 2021).

51. UNESCO World Water Assessment Programme. Where is Water; UNESCO World Water Assessment Programme: Perugia, Italy, 2020. Available online: https:/ / youtu.be/b1f-G6v3voA (accessed on 18 December 2021).

52. Wilkinson, T.J.; Rayne, L.; Jotheri, J. Hydraulic landscapes in Mesopotamia: The role of human niche construction. Water Hist. 2015, 7, 397-418. [CrossRef]

53. Liu, B.; Wang, N.; Chen, M.; Wu, X.; Mo, D.; Liu, J.; Xu, S.; Zhuang, Y. Earliest hydraulic enterprise in China, 5100 years ago Proc. Natl. Acad. Sci. USA 2017, 114, 13637-13642. [CrossRef]

54. Haidvogl, G. Chapter 2: Historic Milestones of Human River Uses and Ecological Impacts. In Riverine Ecosystem Management_Science for Governing Towards a Sustainable Future; Schmutz, S., Sendzimir, J., Eds.; Springer Open: Berlin/Heidelberg, Germany, 2018; Volume 8, pp. 19-39, ISBN 978-3-319-73250-3. Available online: https://www.springer.com/de/book/97833197 32497 (accessed on 18 December 2021).

55. Schmutz, S.; Sendzimir, J. Riverine Ecosystem Management-Science for Governing Towards a Sustainable Future; Springer Open: Berlin/Heidelberg, Germany, 2018; Volume 8, ISBN 978-3-319-73250-3. Available online: https:/ /www.springer.com/de/book/ 9783319732497 (accessed on 18 December 2021).

56. Zeiringer, B.; Seliger, C.; Greimel, F.; Schmutz, S. Chapter 4: River Hydrology, Flow Alteration, and Environmental Flow. In Riverine Ecosystem Management_Science for Governing Towards a Sustainable Future; Schmutz, S., Sendzimir, J., Eds.; Springer Open: Berlin/Heidelberg, Germany, 2018; Volume 8, pp. 67-89, ISBN 978-3-319-73250-3. Available online: https://www.springer.com/ de/book/9783319732497 (accessed on 18 December 2021). 
57. Schmutz, S.; Moog, O. Chapter 6: Dams: Ecological Impacts and Management. In Riverine Ecosystem Management-Science for Governing Towards a Sustainable Future; Schmutz, S., Sendzimir, J., Eds.; Springer Open: Berlin/Heidelberg, Germany, 2018; Volume 8, pp. 111-127, ISBN 978-3-319-73250-3. Available online: https://www.springer.com/de/book/9783319732497 (accessed on 18 December 2021).

58. Hauer, C.; Leitner, P.; Unfer, G.; Pulg, U.; Habersack, H.; Graf, W. Chapter 8. The Role of Sediment and Sediment Dynamics in the Aquatic Environment. In Riverine Ecosystem Management-Science for Governing Towards a Sustainable Future; Schmutz, S., Sendzimir, J., Eds.; Springer Open: Berlin/Heidelberg, Germany, 2018; Volume 8, pp. 151-169, ISBN 978-3-319-73250-3. Available online: https:/ / www.springer.com/de/book/9783319732497 (accessed on 18 December 2021).

59. Hauer, C.; Wagner, B.; Aigner, J.; Holzapfel, P.; Flödl, P.; Liedermann, M.; Tritthart, M.; Sindelar, C.; Pulg, U.; Klösch, M.; et al. State of the art, shortcomings and future challenges for a sustainable sediment management in hydropower: A review. Renew. Sustain. Energy Rev. 2018, 98, 40-55. [CrossRef]

60. Greimel, F.; Schülting, L.; Graf, W.; Bondar-Kunze, E.; Auer, S.; Zeiringer, B.; Hauer, C. Chapter 5: Hydropeaking Impacts and Mitigation. In Riverine Ecosystem Management-Science for Governing Towards a Sustainable Future; Schmutz, S., Sendzimir, J., Eds.; Springer Open: Berlin/Heidelberg, Germany, 2018; Volume 8, pp. 91-110, ISBN 978-3-319-73250-3. Available online: https:/ / www.springer.com/de/book/9783319732497 (accessed on 18 December 2021).

61. Seliger, C.; Zeiringer, B. Chapter 9: River Connectivity, Habitat Fragmentation and related Restoration Measures. In Riverine Ecosystem Management-Science for Governing Towards a Sustainable Future; Schmutz, S., Sendzimir, J., Eds.; Springer Open: Berlin/Heidelberg, Germany, 2018; Volume 8, pp. 171-186, ISBN 978-3-319-73250-3. Available online: https:/ / www.springer. com/de/book/9783319732497 (accessed on 18 December 2021).

62. Schleker, T.; Fjeldstad, H.-P. Hydropower and fish-Report and messages from workshop on research and innovation in the context of the European policy framework. Sci. Total Environ. 2019, 647, 1368-1372. [CrossRef]

63. Kirchherr, J.; Ahrenshop, M.-P.; Charles, K. Resettlement lies: Suggestive evidence from 29 large dam projects. World Dev. 2019, 114, 208-219. [CrossRef]

64. Sternberg, R. Hydropower: Dimensions of social and environmental coexistence. Renew. Sustain. Energy Rev. 2008, 12, 1588-1621. [CrossRef]

65. Buytaert, W.; Zulkafli, Z.; Grainger, S.; Acosta, L.; Alemie, T.C.; Bastiaensen, J.; De Bièvre, B.; Bhusal, J.; Clark, J.; Dewulf, A.; et al. Citizen science in hydrology and water resources: Opportunities for knowledge generation, ecosystem service management, and sustainable development. Front. Earth Sci. 2014, 2, 00026. [CrossRef]

66. Hess, C.E.E.; Fenrich, E. Socio-environmental conflicts on hydropower: The São Luiz do Tapajós project in Brazil. Environ. Sci. Policy 2017, 73, 20-28. [CrossRef]

67. Llamosas, C.; Sovacool, B.K. The future of hydropower? A systematic review of the drivers, benefits and governance dynamics of transboundary dams. Renew. Sustain. Energy Rev. 2021, 137, 110495. [CrossRef]

68. Di Baldassarre, G.; Sivapalan, M.; Rusca, M.; Cudennec, C.; Garcia, M.; Kreibich, H.; Konar, M.; Mondino, E.; Mard, J.; Pande, S.; et al. Sociohydrology: Scientific Challenges in Addressing the Sustainable Development Goals. Water Resour. Res. 2019, 55, 6327-6355. [CrossRef]

69. Habersack, H.; Wagner, B.; Hauer, C.; Jäger, E.; Krapesch, G.; Strahlhofer, L.; Volleritsch, M.; Holzapfel, P.; Schmutz, S.; Schinegger, R.; et al. Entwicklung eines Decision Support Systems zur Beurteilung des Wechselwirkungen zwischen Klimawandel, Energie aus Wasserkraft und Ökologie (Development of Decision Support System to Evaluate the Interactions between Climate Change, Energy, Hydropower and Ecology); Final Report; Klima und Energiefond: Vienna, Austria, 2011; 132p. Available online: https://www.klimafonds. gv.at/wp-content/uploads/sites/16/20150716Decision-Support-SystemsEBKFF07A760480.pdf (accessed on 18 December 2021). (In German) 